\title{
GRAMMATICAL COHESION CONJUNCTION OF 99 CAHAYA DI LANGIT EROPA NOVEL BY HANUM SALSABIELA RAIS AND RANGGA ALMAHENDRA
}

\author{
Eko Yulianto \\ Universitas Indraprasta PGRI \\ Jl. Nangka No. 58C Tanjung Barat, Jagakarsa, Jakarta Selatan, Kode Pos, Indonesia \\ e-mail: antopujifafafa@gmail.com
}

\begin{abstract}
This article contains the results of research on discourse analysis of 99 Cahaya di Langit Eropa which is one of the best-selling novel in Indonesia. In addition to positioning the novel as a literary work, also need to analyze the novel in terms of linguistics. The purpose of this study was to determine the grammatical cohesion contained in the novel, specifically the conjuncture grammatical cohesion. This study uses qualitative content analysis techniques, sampling by way of reduction of the content of the novel. This research analyzes the use of grammatical conjunctions cohesion on the novel, which consists of grammatical cohesion adversative conjunctions, temporal, causal, and additives. The results of sample of 90 paragraphs, consisting of 263 pairs of sentences, $23(8.75 \%)$ pairs of sentences were found to have conjunctural grammatical cohesion, and $240(91.25 \%)$ sentences that didn't have conjunctural grammatical marker relationships.
\end{abstract}

Keywords: discourse, cohesion, conjunctions, novel.

Article History: Received: 12/06/2020; Revised: 14/06/2020; Accepted: 30/06/2020; Published: 16/07/2020

How to Cite (MLA 7th): Yulianto, Eko. “Grammatical Cohesion Conjunction of 99 Cahaya di Langit Eropa Novel by Hanum Salsabiela Rais and Rangga Almahendra." Hortatori Jurnal Pendidikan Bahasa dan Sastra Indonesia vol. 4, no. 1, 2020, 9-13. Print/Online. Copyrights Holder: Eko Yulianto. First Publication: Hortatori Jurnal Pendidikan Bahasa dan Sastra Indonesia (2020).

\section{(i) (2)}

This work is licensed under a Creative Commons Attribution-ShareAlike 4.0 International License.

\section{Pendahuluan}

Pemahaman novel melalui analisis unsur-unsur intrinsik tentu saja belum sampai pada tahap apresiasi sastra. Penghayatan atas sebuah novel hanya dapat dilakukan apabila kita telah membaca teks secara keseluruhan. Dalam proses penghayatan diperlukan pengetahuan tentang bagaimana memahami kalimat demi kalimat yang menyusun sebuah paragraf. Dengan demikian pembaca dapat memahami karakter tokoh, alur, latar, tema, serta amanat secara lebih baik dan utuh. Cara untuk memahaminya adalah membaca tiap kalimat novel, baru pembaca dapat memahami dan mengapresiasi karya sastra tersebut. Penulis tidak bisa asal-asalan dalam membuat kalimat dalam sebuah karya sastra, tetap ada unsur linguistik yang harus dipenuhi, salah satunya adalah dengan menggunakan kata penghubung dalam memadukan antarkalimat dan antarparagraf.

Di samping analisis dari segi sastra, masih diperlukan analisis teks sastra dari segi linguistik, yakni dengan melihat adanya hubungan di dalam kalimat itu sendiri maupun hubungan antarkalimat yang tersusun menjadi sebuah paragraf, kemudian antarparagraf tersebut menyusun sebuah wacana utuh. Wacana yang baik adalah wacana yang harus memperhatikan hubungan antarkalimat (Saputro dan Sevira, 2020:76)

Analisis wacana adalah analisis terhadap bahasa yang digunakan dalam sebuah wacana. Melalui langkah tersebut maka akan diperoleh gambaran yang lebih lengkap tentang bahasa yang digunakan dalam teks. Dalam hal ini menganalisis karya sastra, khususnya novel, selain melihat hubungan antarkalimat, analisis dapat kita lakukan dengan melihat hubungan kohesi. Dengan mengetahui 
kedudukan kata demi kata sebagai unsur penting dalam memahami kalimat maupun wacana, maka kita menjadi lebih dapat memahami sebuah karya sastra, khususnya novel dengan lebih baik. Artinya, dengan menganalisis karya sastra melalui hubungan kohesinya, pemahaman sastra kita menjadi lebih baik. Apresiasi sastra seperti inilah yang sesungguhnya ingin kita capai. Kohesi adalah aspek yang menjalankan keterkaitan kalimat dengan kalimat, paragraf dengan paragraf, atau bab dalam bab sebuah wacana (Achmad, 2005:1). Keterkaitan antarkalimat ditandai dengan adanya unsur gramatikal atau semantik secara eksplisit.

Arifin, dkk. (2014,51) mengungkapkan bahwa ada dua jenis kohesi, yaitu kohesi gramatikal dan kohesi leksikal. Setiap kohesi memiliki sifat relasi masing-masing, yang menunjukkan pertalian bentuk, pertalian referensi, ataupun pertalian makna.

Kridalaksana (1984) berpendapat bahwa wacana (discourse) merupakan Bahasa terlengkap; dalam hierarki gramatikal merupakan satuan gramatikal tertinggi atau terbesar. Wacana tersebut direalisasikan dalam bentuk karangan yang utuh (novel, buku, seri ensiklopedia, dan sebagainya), paragraf, kalimat atau kata yang membawa amanat yang lengkap (dikutip dalam dalam Tarigan, 2009:24).

Achmad (2005:3) menyatakan bahwa kohesi gramatikal adalah pertautan bentuk antara kalimat-kalimat yang diwujudkan dalam sistem gramatikal (pemarkah gramatikal). Dalam kohesi gramatikal alat yang digunakan berupa unsur-unsur kaidah bahasa. Pada umumnya dalam bahasa Indonesia digunakan alat kohesi gramatikal: (1) konjungsi, (2) substitusi, (3) ellipsis, dan (4) rujukan. Ahmad (2005:7-9) membedakan konjungsi dalam bahasa Indonesia menjadi beberapa macam, yakni: (1) konjungsi aditif, (2) konjungsi kausalitas, (3) konjungsi temporal, dan (4) konjungsi adversatif.

Peneliti tertarik membuktikan teori Achmad di atas, bahwa dengan adanya hubungan kohesi konjungsi pada wacana, akan membuat wacana tersebut mudah untuk dipahami, khususnya wacana sastra seperti novel. Pada penelitian sebelumnya yang relevan dalam jurnal Disastra (Saputro dan Sevira, 2020: 75-85) menganalisis kohesi gramatikal konjungsi dalam wacana novel Ayah karya Andrea Hirata, hasilnya dalam novel tersebut terdapat kohesi konjungsi koordinatif, konjungsi subordinatif, konjungsi korelatif, konjungsi antarkalimat, konjungsi antarparagraf. Dari analisis kohesi gramatikal konjungsi tersebut, dapat dilihat bahwa konjungsi yang paling banyak digunakan dalam penulisan novel Ayah karya Andrea Hirata tersebut adalah konjungsi subordinatif.

Peneliti dapat menyimpulkan dari penelitian tersebut bahwa memang keberadaan konjungsi membuat pemaknaan antarkalimat dan antarparagraf jadi lebih baik, bacaan dalam novel seperti mengalir dengan kata-kata penghubung yang digunakan. Lalu, muncul pertanyaan apa pada setiap novel selalu digunakan konjungsi? Maka peneliti mencoba untuk menganalisis wacana novel yang juga populer, yaitu 99 Cahaya di Langit Eropa. Peneliti berusaha untuk melihat penggunaan konjungsi, khususnya konjungsi gramatikal yang terdapat dalam novel tersebut.

\section{Metode}

Sumber data berasal dari hasil reduksi seluruh paragraf yang ada dalam novel 99 Cahaya di Langit Eropa, maka didapatkan paragraf yang dijadikan data sebanyak 90 paragraf, yang terdiri dari 263 pasang kalimat yang dianalisis.

Metode yang digunakan dalam penelitian ini adalah metode kualitatif dengan teknik analisis isi (content analysis). Penelitian ini adalah penelitian deskriptif, yakni mendeskripsikan data berupa pasangan kalimat dalam paragraf yang menyusun wacana novel. Oleh karena itu, hasil penelitian ini adalah berupa kutipan pasangan-pasangan kalimat dari paragraf yang telah dipilih yang selanjutnya dianalisis menggunakan alat kohesi gramatikal konjungsi. Analisis isi yang dilakukan adalah dengan mengumpulkan data, kemudian data tersebut diolah, dianalisis, dan langkah akhirnya adalah intrepretasi hasil temuan dan disajikan dalam bentuk tabel. Bagan alir penelitiannya adalah sebagai berikut:

Bagan 1. Alir Penelitian

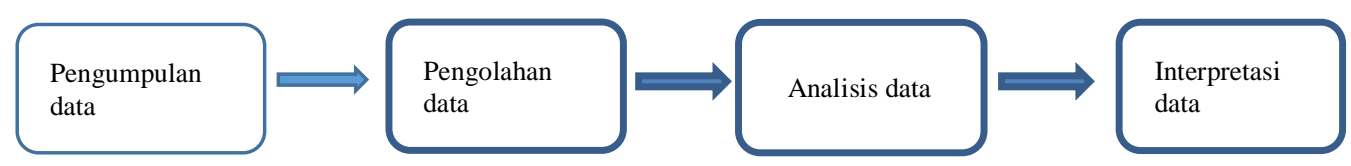


Pengecekan keabsahan data dilakukan dengan teknik triangulasi data, yaitu dengan membandingkan dengan hasil penelitian yang lain. Fokus penelitian adalah pada kohesi gramatikal konjungsi yang terdapat dalam novel. Subfokus pada penelitian ini adalah kohesi gramatikal konjungsinya yaitu, adversatif, temporal, aditif, dan kausalitas.

\section{Hasil dan Diskusi}

Penelitian kohesi gramatikal Novel 99 Cahaya di Langit Eropa karya Hanum Salsabiela Rais dan Rangga Almahendra ini mengambil reduksi data 17 bab dari seluruh bab yang berjumlah 52 bab. Sampel diperoleh berdasarkan persentase tiap bab dengan mengabaikan wacana dialog karena wacana tersebut tidak diteliti.

Berdasarkan ketujuh belas judul bab, diperoleh 90 paragraf yang terdiri dari 260 pasangan kalimat. Seluruh pasangan kalimat yang menjadi data penelitian diketik ulang, diberi nomor, kemudian dianalisis penggunaan pemarkah kohesi gramatikalnya. Setelah analisis, pasangan kalimat tersebut dimasukkan ke dalam tabel analisis kerja. Selanjutnya membuat deskripsi data aspek kohesi gramatikal konjungsi perjudul dan aspek kohesi gramatikal seluruh judul. Berikut ini adalah contoh temuan kohesi gramatikal yang terdapat dalam novel:

\section{Aditif}

Pasangan kalimat:

Baru dua Minggu kami berkenalan.

Dan pucuk dicinta ulam tiba, dia seakan tahu aku perlu seorang penunjuk jalan untuk menyusuri sudut-sudut kota Wina.

Analisis:

Kata "dan" pada kalimat dua memiliki keterkaitan dengan kalimat satu secara gramatikal konjungsi aditif.

Simpulan:

Jadi, pasangan kalimat tiga belas dipertautkan oleh pemarkah kohesi gramatikal konjungsi aditif.

\section{Kausalitas}

Pasangan kalimat:

Sesuai namanya Kahlenberg, "kahl" dalam bahasa Jerman berarti telanjang, sementara "berg" pegunungan.

Jadi, kira-kira maksud si pemberi nama pegunungan ini kala itu adalah dari sini orang bisa menelanjangi kota Wina seutuhnya tanpa batas.

Analisis:

Kata "jadi" pada kalimat empat memiliki hubungan pemarkah kohesi gramatikal konjungsi kausalitas dengan kalimat tiga.

Simpulan:

Pasangan kalimat dua puluh memiliki hubungan pemarkah kohesi gramatikal konjungsi kausalitas.

\section{Temporal}

Pasangan kalimat:

Dia mengeluarkan sebongkah daging yang cukup besar, lalu meletakkannya di meja di luar kedai.

Kemudian dengan cetakan Pak Tua itu menghunuskan pisau besar dari balik sakunya.

Analisis:

Kata "kemudian" pada kalimat tiga memiliki hubungan pemarkah kohesi dengan kalimat dua, yaitu kohesi gramatikal konjungsi temporal.

Simpulan:

Pasangan kalimat seratus tujuh puluh enam memiliki hubungan kohesi gramatikal konjungsi temporal.

\section{Adversatif}

Pasangan kalimat:

Seharusnya burung-burung sudah berkicau menyambut matahari yang terlalu irit cahaya pada 6 bulan sebelumnya.

Tetapi nyatanya itu tidak terjadi.

Analisis:

Kata "tetapi" pada kalimat empat merujuk kepada kalimat tiga sebagai konjungsi adversatif, karena keduanya menunjukkan pertentangan atau kekontrasan. 
Simpulan:

Jadi, pasangan kalimat lima dipertautkan oleh pemarkah kohesi gramatikal konjungsi adversatif.

Tabel 1. Analisis Seluruh Paragraf

\begin{tabular}{ccccccc}
\hline \multirow{2}{*}{$\begin{array}{c}\text { Pasangan } \\
\text { Kalimat }\end{array}$} & \multicolumn{2}{c}{ Kohesi } & & \multicolumn{2}{c}{ Kohesi Gramatikal Konjungsi } \\
& Ya & Tidak & Aditif & Kausalitas & Temporal & Adversatif \\
\cline { 2 - 7 } & 23 & 240 & 4 & 5 & 4 & 10 \\
\hline $\mathbf{2 6 3}$ & & & & 5 & 4 \\
\hline
\end{tabular}

Tabel 2. Pasangan Kalimat Berkohesi dan Tidak Berkohesi Gramatikal Konjungsi Novel 99 Cahaya di Langit Eropa

\begin{tabular}{ccc}
\hline Berkohesi/Tidak Berkohesi & Jumlah & Persentase \\
\hline Berkohesi & 23 & $8,75 \%$ \\
\hline Tidak berkohesi & 240 & $91,25 \%$ \\
\hline Jumlah & $\mathbf{2 6 3}$ & $\mathbf{1 0 0 \%}$ \\
\hline
\end{tabular}

Tabel 3. Persentase Analisis Aspek Kohesi Gramatikal Konjungsi Novel 99 Cahaya di Langit Eropa

\begin{tabular}{lccc}
\hline & $\begin{array}{c}\text { Aspek Analisis } \\
\text { Konjungsi }\end{array}$ & Jumlah & Persentase \\
\hline Aditif & & $1,52 \%$ \\
\hline Kausalitas & 5 & $1,90 \%$ \\
\hline Temporal & 4 & $1,52 \%$ \\
\hline Adversatif & & 10 & $3,81 \%$ \\
\hline & Jumlah & $\mathbf{2 3}$ & $\mathbf{8 , 7 5 \%}$ \\
\hline
\end{tabular}

Dari hasil reduksi seluruh paragraf yang ada dalam novel 99 Cahaya di Langit Eropa, maka didapatkan paragraf yang dijadikan sampel sebanyak 90 paragraf, yang terdiri dari 263 pasang kalimat yang dianalisis. Dari pasangan-pasangan kalimat tersebut, ditemukan $23(8,75 \%)$ pasang kalimat yang memiliki hubungan pemarkah kohesi gramatikal konjungsi, dan $240(91,25 \%)$ kalimat yang tidak memiliki hubungan pemarkah gramatikal konjungsi. Pasangan-pasangan kalimat yang memiliki hubungan pemarkah kohesi gramatikal konjungsi terdiri dari 4 pasangan kalimat yang memiliki hubungan pemarkah kohesi aditif dengan persentase 1,52\%, 5 pasangan kalimat yang memiliki hubungan pemarkah kohesi kausalitas dengan persentase 1,90\%, 4 pasangan kalimat yang memiliki hubungan pemarkah kohesi temporal dengan persentase $1,52 \%$, dan 10 pasangan kalimat yang memiliki hubungan pemarkah kohesi adversatif dengan persentase $3,81 \%$.

\section{Simpulan}

Berdasarkan hasil analisis data dan pembahasan yang telah dilakukan pada bab-bab sebelumnya, maka dalam penelitian ini dapat ditarik simpulan sebagai berikut:

1. Dari hasil reduksi seluruh paragraf yang ada dalam novel 99 Cahaya di Langit Eropa, maka didapatkan paragraf yang dijadikan sampel sebanyak 90 paragraf, yang terdiri dari 263 pasang kalimat yang dianalisis.

2. Dari pasangan-pasangan kalimat tersebut, ditemukan $23(8,75 \%)$ pasang kalimat yang memiliki hubungan pemarkah kohesi gramatikal konjungsi, dan $240(91,25 \%)$ kalimat yang tidak memiliki hubungan pemarkah gramatikal konjungsi. 
3. Pasangan-pasangan kalimat yang memiliki hubungan pemarkah kohesi gramatikal konjungsi terdiri dari 4 pasangan kalimat yang memiliki hubungan pemarkah kohesi aditif dengan persentase 1,52\%, 5 pasangan kalimat yang memiliki hubungan pemarkah kohesi kausalitas dengan persentase 1,90\%, 4 pasangan kalimat yang memiliki hubungan pemarkah kohesi temporal dengan persentase $1,52 \%$, dan 10 pasangan kalimat yang memiliki hubungan pemarkah kohesi adversatif dengan persentase 3,81\% .

4. Analisis kohesi gramatikal dapat dijadikan sebagai bahan latihan dalam menganalisis sastra, khususnya novel yang selama ini hanya diteliti unsur sastranya saja. Dengan meneliti unsur bahasanya, dalam hal ini kohesi gramatikal, pembaca dapat memahami wacana novel dengan lebih baik. Artinya, penelitian aspek kohesi gramatikal dapat membantu apresiasi sastra, khususnya novel secara lebih baik.

\section{Ucapan Terima Kasih}

Ucapan terima kasih disampaikan pada semua pihak yang telah berkontribusi dan membantu dalam penelitian ini, seperti LPPM Universitas Indraprasta PGRI, beserta rekan dosen sejawat yang banyak memberikan masukan dan saran. Terima kasih pula kepada tim editor jurnal Hortatori yang telah memberikan arahan untuk memublikasikan hasil penelitian ini.

\section{Daftar Rujukan}

Arifin, E. Zaenal, dkk. Wacana Transaksional dan Interaksional dalam Bahasa Indonesia. Tangerang: Pustaka Mandiri. 2015.

HP. Ahmad. Modul Aspek Kohesi Wacana. Jakarta: Fakultas Bahasa dan Seni Universitas Negeri Jakarta. 2005.

Saputro, Ardiana Artati, dan Endah Ridha Sevira, "Analisis Kohesi Gramatikal Konjungsi dalam Wacana Novel Ayah Karya Andrea Hirata.” Jurnal Disastra, vol. 2, no. 1, 2020, 75-85.

Tarigan, Henry Guntur. Pengajajaran Wacana. Bandung: Angkasa. 2009. 